\title{
KANET in Brazil: First Experience
}

\author{
Raul Moreira Neto
}

\begin{abstract}
Objective: The goal of this pilot test is to compare Kurjak's antenatal neurological test (KANET) results between high and low-risk pregnancies and see the feasibility of using this test on a larger scale in Brazil.
\end{abstract}

Methods: We applied KANET test in high-risk $(\mathrm{n}=17)$ and low-risk $(n=34)$ pregnancies and compared the results.

Results: There was a significant difference between groups of high-risk and low-risk pregnancies for all parameters in KANET score 2. For KANET score 0,5 out of 8 parameters where significant different: isolated head anteflexion, cranial sutures and head circumference, isolated hand movement or hand to face movements, isolated leg movement and fingers movements. All abnormal KANET result came from high-risk pregnancies (17.6\%). No low-risk pregnancies presented KANET score 0 . Efficacy and effectiveness were not evaluated due to the imprecision inherent in data from small samples.

Conclusion: This successful preliminary study of KANET in Brazil showed important differences in fetal behavior between the low and high-risk pregnancies, and can be used as information of feasibility and identify modifications needed in the design of a larger testing study.

Keywords: Fetal behavior, Four-dimensional ultrasound, KANET, Neurodevelopment prenatal assessment, Fetal central nervous system.

How to cite this article: Neto RM. KANET in Brazil: First Experience. Donald School J Ultrasound Obstet Gynecol 2015;9(1):1-5.

\section{Source of support: Nil}

Conflict of interest: None declared.

\section{INTRODUCTION}

Over the past 30 years, emerged the most important results on fetal behavior, through the evolution of ultrasound and important research of basic neurological development. It is increasingly evident that many severe neurological disorders, or minimal cerebral dysfunctions, originate from the intrauterine, instead of the perinatal or early postnatal period. ${ }^{1,2}$

After fetal behavior has been compared with morphological studies, investigators have come to conclusion that

Department of Fetal Medicine, Ecomoinhos—School and Clinic of Ultrasonography, Porto Alegre, Brazil

Corresponding Author: Raul Moreira Neto, Ecomoinhos, rua Tobias da Silva 120/501, CEP 90570-020, Porto Alegre, RS, Brazil Phone: (55)51-3346-2111, e-mail: raul@ecomoinhos.com.br fetal behavioral patterns directly reflect developmental and maturational processes of fetal central nervous system (CNS). Since, fetal brain impairment could interfere with the internal motor activity and fetal movements (or behavior) this could be used as a marker for fetal brain optimality. ${ }^{3-7}$ Therefore, it was proposed that the evaluation of fetal behavior could give the possibility to discriminate between normal and abnormal brain development, likewise an early diagnosis of different structural or functional abnormalities. ${ }^{3}$

The challenge of modern perinatal medicine is to assess the integrity of fetal and neonatal CNS especially since many important functional neurological abnormalities such as cerebral palsy (CP) are still poorly understood..$^{8}$

The discovery of the continuity of neurological activity generated from the prenatal period to postnatal life, allowed the identification of those fetuses that could develop a postnatal neurological impairment. 3,4,9-12

The interest in fetal behavior started a long time ago with two-dimensional (2D) ultrasound. ${ }^{13-15}$ Although 2D ultrasonography documents specific fetal movements, only the number of movements was seen, not the quality. More importantly, simultaneous imaging of complex facial movements was impossible using only a 2D ultrasound. ${ }^{16,17}$

A technique was needed to enable three-dimensional (3D) imaging of fetal facial movements in real-time mode. This technique was introduced a 4D ultrasound (3D in real time).

The first studies on fetal behavior by $4 \mathrm{D}$ ultrasound (4D US) validated that this method could help in better understandment of neurosomatic development of the fetus, beginning a new era in the understanding of neurological diseases that start during intrauterine life. 3,18-21

Thus, it was suggested that the assessment of fetal behavior in different periods of pregnancy could distinguish between normal and abnormal brain development and early diagnosis of various structural or functional abnormalities. $^{3}$

For evaluation of fetal behavior, Kurjak et al introduced and described original scoring system called Kurjak's antenatal neurological test (KANET). ${ }^{22}$

The parameters used in the test arose from a multicenter survey results conducted earlier on fetal neurobehavioral assessed by 2D ultrasound (2D US) and combined with neonatal signs suggested by AmielTison. ${ }^{21,23,24}$ 
The primary goal of this pilot study test was to see the feasibility of using KANET in high-risk and lowrisk pregnancies in Brazil, to develop and test adequacy of research instruments, assessing the possibility of a full-scale study in a reference hospital and designing a research protocol.

\section{PATIENTS AND METHODS}

During a period of almost 2 months, between November and December of 2014, KANET was applied in 51 singleton pregnancies between 28th and 38th weeks of gestation. Gestational age was estimated by the first day of last menstrual period and confirmed by the first ultrasound assessment.

Fetal behavior was assessed by 4D US. All examinations were performed by a single experienced operator using Voluson E8 (GE Healthcare ultrasound, Milwaukee, WI, USA), with volumetric transabdominal $5 \mathrm{MHz}$ transducer.

Each participant gave her informed consent to the study.

The study participants were those who came for an ultrasound exam in a private fetal medicine clinic, in Porto Alegre, Brazil. Were included 17 high-risk and 34 low-risk pregnancies as controls. The inclusion criteria for high-risk pregnancies are presented in the Table 1.

For assessment of fetal neurobehavior, we used a KANET scoring system ${ }^{22}$ presented in Table 2.

Table 3 shows the interpretation of the KANET scores.

After a systematic 2D measurement of fetal growth and examination of placenta and amniotic fluid volume, the mothers were offered an assessment of fetal behavior by KANET scoring system, using 4D US. The exam was performed while fetuses were awake. Mothers should avoid food, coffee and tea for 2 hours before the examination. The examination maximum time was 30 minutes. According to the score result, fetal behavior was classified into three groups: normal, with total KA-

Table 1: Inclusion criteria

\begin{tabular}{ll}
\hline Family history & $\begin{array}{l}\text { Previous child with cerebral palsy } \\
\text { Maternal condition } \\
\text { Diabetes mellitus type I and II, thyroid } \\
\text { disease, preexistent hypertension, drug } \\
\text { abuse, thrombophilia, anemia, epilepsy, } \\
\text { fever }>39^{\circ} \mathrm{C}\end{array}$ \\
$\begin{array}{l}\text { Pregnancy-related } \\
\text { disorders }\end{array}$ & $\begin{array}{l}\text { Gestational diabetes, Rh immunization, } \\
\text { threatened preterm labor, } \\
\text { preeclampsia, intrauterine infections, } \\
\text { viral illness, cholestasis }\end{array}$ \\
& $\begin{array}{l}\text { Structural and chromosomal } \\
\text { abnormalities, polyhydramnion, } \\
\text { intrauterine growth restriction, abnormal } \\
\text { cardiotocography, biophysical profile } \\
\text { and Doppler findings }\end{array}$ \\
\hline
\end{tabular}

NET score of 10 to 16 , borderline with total score of 6 to 9 and abnormal with total score of $£ 5$.

The description and the meaning of each specific movement and sign of KANET is described elsewhere. ${ }^{28}$

The primary outcome was the usefulness of KANET to identify fetuses from high-risk pregnancies at neurological risk. Then we want to compare the scores between the high-risk and low-risk group and, also, compare the KANET results between the high-risk group and subgroups of fetuses. Due to relatively small sample size statistical analysis is at present impossible.

\section{RESULTS}

In this prospective longitudinal study, the KANET was applied in 51 singleton pregnancies between 28 and 38 weeks of gestation. There were 17 pregnant women in the high-risk group and 34 pregnant women in low-risk group.

The final results of KANET study, only high-risk patients showed abnormal scores (17.6\%). 80.6\% of highrisk patients had borderline results while $85.3 \%$ of lowrisk patients were normal, both statistically significant. Table 4 shows the allocation of fetuses according to KANET.

The comparison of individual parameters for KANET score 0 , between fetuses of low and high-risk pregnancies, there was a statistically significant difference for isolated head anteflexion, cranial sutures and head circumference, isolated hand movement or hand to face movements, isolated leg movement and fingers movements. There was no difference between isolated eye blinking, facial movements or mouth opening and gestalt perception of general movements.

On other hand, for KANET score 2, there was significant difference between all the parameters. Table 5 shows the comparison of individual parameters in KANET.

For the three abnormal KANET results (score between 0 and 5), one was related to pregnancy condition (preeclampsia) and two were related to fetal condition (trisomy 13 and Intrauterine growth restriction).

Table 6 presents individual participants assigned to the high-risk group according to prenatal diagnosis.

\section{CONCLUSION}

In the last three decades, there have been several attempts to create a diagnostic test for assessment of fetal behavior. Although several were important, none of them was implemented in daily practice. ${ }^{22,25-27}$ KANET is the first prenatal neurological screening test based on $4 \mathrm{D}$ US technique and the first results are encouraging. . $^{13-15,28-30}$ We believe that KANET can separate serious structural 
Table 2: Scoring system of Kurjak antenatal neurodevelopmental test (KANET)

\begin{tabular}{|c|c|c|c|}
\hline \multirow[t]{2}{*}{ Sign } & \multicolumn{3}{|c|}{ Score } \\
\hline & 0 & 1 & 2 \\
\hline Isolated head anteflexion & Abrupt & $\begin{array}{l}\text { Small range } \\
\text { (0-3 times of movements) }\end{array}$ & $\begin{array}{l}\text { Variable in full range, } \\
\text { many alteration ( }>3 \text { times } \\
\text { of movements) }\end{array}$ \\
\hline $\begin{array}{l}\text { Cranial sutures and head circumference } \\
\end{array}$ & $\begin{array}{l}\text { Overlapping of cranial } \\
\text { sutures }\end{array}$ & $\begin{array}{l}\text { Normal cranial sutures } \\
\text { with measurement of } \\
\mathrm{HC} \text { below or above the } \\
\text { normal limit ( }-2 \mathrm{SD}) \\
\text { according to GA }\end{array}$ & $\begin{array}{l}\text { Normal cranial sutures } \\
\text { with normal measurement } \\
\text { of } \mathrm{HC} \text { according to GA }\end{array}$ \\
\hline Isolated eye blinking & Not present & $\begin{array}{l}\text { Not fluent (1-5 times of } \\
\text { blinking) }\end{array}$ & $\begin{array}{l}\text { Fluency (>5 times of } \\
\text { blinking) }\end{array}$ \\
\hline Facial alteration (grimace or tongue expulsion) & Not present & $\begin{array}{l}\text { Not fluent ( } 1-5 \text { times of } \\
\text { alteration) }\end{array}$ & $\begin{array}{l}\text { Fluency }(>5 \text { times of } \\
\text { alteration) }\end{array}$ \\
\hline Isolated leg movement & Cramped & $\begin{array}{l}\text { Poor repertoire or small } \\
\text { in range ( } 0-5 \text { times of } \\
\text { movement) }\end{array}$ & $\begin{array}{l}\text { Variable in full range, } \\
\text { many alternation } \\
\text { ( }>5 \text { times of movement) }\end{array}$ \\
\hline Isolated hand movement & Cramped or abrupt & $\begin{array}{l}\text { Poor repertoire or small } \\
\text { in range }(0-5 \text { times of } \\
\text { movement })\end{array}$ & $\begin{array}{l}\text { Variable in full range, } \\
\text { many alternation } \\
\text { ( }>5 \text { times of movements) }\end{array}$ \\
\hline Fingers movements & $\begin{array}{l}\text { Unilateral or bilateral } \\
\text { clenched fist, } \\
\text { (neurological thumb) }\end{array}$ & $\begin{array}{l}\text { Cramped invariable } \\
\text { finger movements }\end{array}$ & $\begin{array}{l}\text { Smooth and complex, } \\
\text { variable finger } \\
\text { movements }\end{array}$ \\
\hline Gestalt perception of GMS & Definitely abnormal & Borderline & Normal \\
\hline
\end{tabular}


Table 3: Interpretation of total score

\begin{tabular}{ll}
\hline Total score & Interpretation \\
\hline $0-5$ & Abnormal \\
$6-9$ & Borderline \\
$10-16$ & Normal \\
\hline
\end{tabular}

Table 4: Interpretation of KANET score in low and high-risk pregnancies

\begin{tabular}{lll}
\hline $\begin{array}{l}\text { Total score } \\
\text { interpretation }\end{array}$ & $\begin{array}{l}\text { High-risk } \\
(n=17)\end{array}$ & $\begin{array}{l}\text { Low-risk } \\
(n=34)\end{array}$ \\
\hline 0-5 Abnormal & $3(17.6 \%)$ & 0 \\
6-9 Borderline & $12(70.6 \%)$ & $5(14.7 \%)$ \\
$10-16$ Normal & $2(11.8 \%)$ & $29(85.3 \%)$ \\
\hline
\end{tabular}

Table 5: Comparison of individual parameters in Kurjak's antenatal neurological test between high-risk and low-risk pregnancies

\begin{tabular}{|c|c|c|c|}
\hline \multirow[t]{2}{*}{ KANET parameters } & \multicolumn{3}{|c|}{ Kanet scores } \\
\hline & 0 & 1 & 2 \\
\hline \multicolumn{4}{|l|}{$\begin{array}{l}\text { Isolated head } \\
\text { anteflexion }\end{array}$} \\
\hline High-risk (n:17) & $5(29.4 \%)$ & $10(58.9 \%)$ & $2(11.7 \%)$ \\
\hline Low-risk $(n=34)$ & 0 & $16(47.1 \%)$ & $18(52.9 \%)$ \\
\hline \multicolumn{4}{|l|}{$\begin{array}{l}\text { Cranial sutures and } \\
\text { head circumference }\end{array}$} \\
\hline High-risk (n:17) & $3(17.6 \%)$ & $6(35.2 \%)$ & $8(47.2 \%)$ \\
\hline Low-risk $(n=34)$ & 0 & $4(11.8 \%)$ & $30(88.2 \%)$ \\
\hline \multicolumn{4}{|l|}{ Isolated eye blinking } \\
\hline High-risk (n:17) & $4(23.5 \%)$ & $7(41.2 \%)$ & $6(35.3 \%)$ \\
\hline Low-risk $(n=34)$ & 0 & $9(37.5 \%)$ & $25(72.5 \%)$ \\
\hline \multicolumn{4}{|l|}{$\begin{array}{l}\text { Facial movements } \\
\text { (grimace or tongue } \\
\text { expulsion) or mouth } \\
\text { opening (yawning or } \\
\text { mouthing) }\end{array}$} \\
\hline High-risk (n:17) & $2(11.7 \%)$ & $8(47.2 \%)$ & $7(41.1 \%)$ \\
\hline Low-risk ( $n=34$ ) & 0 & $10(29.4 \%)$ & $24(70.6 \%)$ \\
\hline \multicolumn{4}{|l|}{$\begin{array}{l}\text { Isolated hand } \\
\text { movement or hand to } \\
\text { face movements }\end{array}$} \\
\hline High-risk (n:17) & $3(17.6 \%)$ & $9(52.9 \%)$ & $5(29.5 \%)$ \\
\hline Low-risk $(n=34)$ & 0 & $9(37.5)$ & $25(72.5)$ \\
\hline \multicolumn{4}{|c|}{ Isolated leg movement } \\
\hline High-risk (n:17) & $4(23.5 \%)$ & $10(58.9 \%)$ & $3(17.6 \%)$ \\
\hline Low-risk $(n=34)$ & 0 & $12(35.2 \%)$ & $22(64.8 \%)$ \\
\hline \multicolumn{4}{|l|}{ Fingers movements } \\
\hline High-risk (n:17) & $6(35.3 \%)$ & $6(35.3 \%)$ & $5(29.4 \%)$ \\
\hline Low-risk $(n=34)$ & 0 & $10(29.4 \%)$ & $24(70.6 \%)$ \\
\hline \multicolumn{4}{|l|}{$\begin{array}{l}\text { Gestalt perception of } \\
\text { general movements }\end{array}$} \\
\hline High-risk (n:17) & $2(11.8 \%)$ & $9(52.9 \%)$ & $6(35.3 \%)$ \\
\hline Low-risk $(n=34)$ & 0 & $9(37.5 \%)$ & $25(72.5 \%)$ \\
\hline
\end{tabular}

problems associated with brain injuries. Therefore, our aim is to assess whether KANET really has the potential for prenatal detection of serious neurological problems as well as other causes. Although promising, the concept
Table 6: High-risk study group according to prenatal diagnosis and KANET results

\begin{tabular}{lllll}
\hline High-risk group & Total & \multicolumn{3}{c}{ KANET results } \\
\cline { 3 - 5 } & & Normal & Borderline & Abnormal \\
\hline Preeclampsia & 3 & 0 & 2 & 1 \\
$\begin{array}{l}\text { Threatened } \\
\text { preterm labor }\end{array}$ & 2 & 0 & 2 & 0 \\
$\begin{array}{l}\text { Preexistent } \\
\text { hypertension }\end{array}$ & 3 & 1 & 2 & 0 \\
Gestational diabetes & 2 & 0 & 2 & 0 \\
$\begin{array}{l}\text { Anemia } \\
\text { Polyhydramnion }\end{array}$ & 1 & 1 & 0 & 0 \\
Intrauterine growth & 4 & 0 & 1 & 0 \\
restriction & & 0 & 3 & 1 \\
Trisomy 13 & 1 & 0 & 0 & 1 \\
\hline Total & 17 & 2 & 12 & 3 \\
\hline
\end{tabular}

of KANET and its diagnostic value in the evaluation of fetal central nervous system integrity must be confirmed by studies that are underway in several research centers around the world, and we want to continue this research in Brazil as well.

In this pilot study, we saw that there are important differences between the behavior of normal and high-risk fetus, which is in agreement with other studies. ${ }^{22,25-27,31-33}$

We also found that the vast majority of high-risk pregnancies had borderline KANET. On the other hand, low-risk pregnancies most often presented normal results. But we need to do a bigger research to see the efficiency and effectiveness of KANET. This project was essential to analyze the feasibility of a study on a larger scale and we saw it was realistic and achievable to adapt the protocols, methods and instruments. In addition, logistical problems have been identified and we saw what resources (financial, staff) are needed for a planned study.

We have reached our goal in the study and found that it is possible to do KANET research on a larger scale in Brazil. We also saw the potential to detect and discriminate normal fetal behavior of borderline and abnormal in high-risk pregnancies using KANET.

\section{REFERENCES}

1. Rees S, Harding R. Brain development during fetal life: influences of the intra-uterine environment. Neursci Lett 2004;361:111-114.

2. Harrison PJ. The neuropathology of schizophrenia. A critical review of the data and their interpretation. Brain 1999;122: 593-624.

3. Prechtl HFR. Qualitative changes of spontaneous movements in fetus and preterm infant are a marker of neurological dysfunction. Early Hum Dev 1990;23:151-158.

4. Hadders-Algra M. General movements: a window for early, identification of children at high-risk of developmental disorders. J Pediatr 2004;145:S12-S18.

5. Cioni G, Prechtl HFR, Ferrari F, Paolicelli PB, Einspieler C, Roversi MF. Which better predicts later outcome in 
full-term infants: Quality of general movements or neurological examination? Early Hum Dev 1997;50:71-85.

6. Einspieler C, Prechtl HFR, Bos AF, Ferrari F, Cioni G. Prechtl's method on the qualitative assessment of general movements in preterm, term and young infants. London: Mac Keith Press 2004.

7. Einspieler C, Prechtl HFR. Prechtl's assessment of general movements: a diagnostic tool for the functional assessment of the young nervous system. Ment Retard Dev Disabil Res Rev 2005;11:61-67.

8. Strijbis EMM, Oudman I, Van Essen P, MacLennan AH. Cerebral palsy and application of the international criteria for acute intrapartum hypoxia. Obstet Gynecol 2006;107:1357-1365.

9. Amiel-Tison A, Gosselin J, Kurjak A. Neurosonography in the second half of fetal life: a neonatologist's point of view. J Perinat Med 2006;34:437-446.

10. Groen SE, de Blecourt AC, Postema K, Hadders-Algra M. General movements in early infancy predict neuromotor development at 9-12 years of age. Dev Med Child Neurol 2005;47:731-738.

11. Hepper PG. Fetal habituation: another Pandora's box? Dev Med Child Neurol 1997;39:274-278.

12. Stanojevic M, Kurjak A, Andonotopo W. Assessment of fetal to neonatal behavioral continuity by $4 \mathrm{D}$ ultrasonography. Ultrasound Obstet Gynecol 2006;28:360.

13. Nijhuis JG, Prechtl HF, Martin CB Jr, Bots RS. Are there behavioural states in the human fetus? Early Hum Dev 1982;6:177-195.

14. Horimoto N, Koyanagi T, Maeda H, Satoh S, Takashima T, Minami T, Nakano H. Can brain impairment be detected by in utero behavioural patterns? Arch Dis Child 1993;69 (1 Spec No):3-8.

15. Prechtl HFR, Einspieler C. Is neurological assessment of the fetus possible? Eur J Obstet Gynecol Reprod Biol 1997;75: 81-84.

16. Arabin B. Two-dimensional real-time ultrasound in the assessment of fetal activity in single and multiple pregnancies. Ultrasound Rev Obstet Gynecol 2004;4:37.

17. Sepulveda W, Mangiamarchi M. Fetal yawning. Ultrasound Obstet Gynecol 1995;5:57.

18. Stanojevic M, Kurjak A, Salihagic-Kadic A, Vasilj O, Miskovic B, Shaddad AN, Ahmed B, et al. Neurobehavioral continuity from fetus to neonate. J Perinat Med 2011;39:171-177.

19. Kuno A, Akiyama M, Yamashiro C, Tanaka H, Yanagihara T, Hata T. Three-dimensional sonographic assessment of fetal behavior $n$ the early second trimester of pregnancy. J Ultrasound Med 2011;20:1271-1275.

20. Horimoto N, Koyanagi T, Satoh S, Yoshizato T, Nakano H. Fetal eye movement assessed with real-time ultrasonography: are there rapid and slow eye movements? Am J Obstet Gynecol 1989;163:1480-1484.

21. Yigiter AB, Kavak ZN. Normal standards of fetal behavior assessed by four-dimensional sonography. J Matern Fetal Neonatal Med 2006;19:707-721.
22. Kurjak A, Miskovic B, Stanojevic M, Amiel-Tison C, Ahmed B, Azumendi G, Vasilj O, Andonotopo W, Turudic T, SalihagicKadic A. New scoring system for fetal neurobehavior assessed by three and four-dimensional sonography. J Perinat Med 2008;36:73-81.

23. Amiel-Tison C. Update of the Amiel-Tison neurological assessment for the term neonate or at 40 weeks corrected age. Pediatr Neurol 2002;27:196-212.

24. Kurjak A, Andonotopo W, Hafner T, Salihagic A, StandojevicM, Azumendi G, et al. Normal standards for fetal neurobehavioral developments-longitudinal quantification by four-dimensional sonography. J Perinat Med 2006;34:56-65.

25. Kurjak A, Abo-Yaqoub S, Stanojevic M, Yigiter AB, Vasilj O, Lebit $\mathrm{D}$, et al. The potential of $4 \mathrm{D}$ sonography in the assessment of fetal neurobehavior: Multicentric study in high-risk pregnancies. J Perinat Med 2010;38(1):77-82.

26. Miskovic B, Vasilj O, Stanojevic M, Ivankovic D, Kerner M, Tikvica A. The comparison of fetal behavior in high-risk and normal pregnancies assessed by four-dimensional ultrasound. J Matern Fetal Neonatal Med 2010 Dec;23(12): 1461-1467.

27. Talic A, Kurjak A, Ahmed B, Stanojevic M, Predojevic M, Salihagic Kadic A, Di Renzo GC. The potential of 4D sonography in the assessment of fetal behavior in high-risk pregnancies. J Matern Fetal Neonatal Med 2011 Jul;24(7): 948-954.

28. Kurjak A, Ahmed B, Abo-Yaguab S, Younis M, Saleh H, Shaddad AN, et al. An attempt to introduce neurological test for fetus based on 3D and 4D sonography. Donald School Journal of Ultrasound in Obstetrics and Gynecology 2008; 2:29-44.

29. Kurjak A, Tikvica Luetic A, Stanojevic M, Talic A, Zalud I, AlNoobi M, et al. Further experience in the clinical assessment of fetal neurobehavior. Donald School J Ultrasound in Obstet and Gynecol 2010;4:59-71.

30. Morokuma S, Fukushima K, Yumoto Y, Uchimura M, Fujiwara A, Matsumoto M, Satoh S, Nakano H. Simplified ultrasound screening for fetal brain function based on behavioral pattern. Early Hum Dev 2007;83:177-1781.

31. Predojević M, Stanojević M, Vasilj O, Kadić AS. Postnatal neurological evaluation of a fetus and newborn from pregnancy complicated with IUGR and fetal hypoxemia. J Matern Fetal Neonatal Med 2011 May;24(5):764-767.

32. Athanasiadis AP, Mikos T, Tambakoudis GP, Theodoridis TD, Papastergiou M, et al. Neurodevelopmental fetal assessment using KANET scoring system in low and high risk pregnancies. J Matern Fetal Neonatal Med 2013;26:363-368.

33. Abo-Yaqoub S, Kurjak A, Mohammed AB, Shadad A, AbdelMaaboud M. The role of 4-D ultrasonography in prenatal assessment of fetal neurobehaviour and prediction of neurological outcome. J Matern Fetal Neonatal Med 2012;25: 231-236. 